Nurreni Irawati et al/Animal Production. 21(1):16-21, 2019

Accredited by Kemenristek Dikti No 32a/E/KPT/2017. ISSN 1411-2027

\title{
Estimating Genetic Parameter of Saanen Goat Production Characteristics using Paternal Halfsib Correlation
}

\author{
Nurreni Irawati*, Datta Dewi Purwantini and Akhmad Sodiq \\ Faculty of Animal Science, Jenderal Soedirman University, Purwokerto, Indonesia \\ *Corresponding author email: nurreni.irawati023@gmail.com
}

\begin{abstract}
This research was aimed to investigate the heritability score $\left(\mathrm{h}^{2}\right)$ of milk yield, kid birth weight, and milk quality that included density, fat content, protein, lactose, water and solids non fat of Saanen goat according to the production record of first-lactating individual in the Balai Besar Pembibitan Ternak Unggul dan Hijauan Pakan Ternak Baturraden. The materials for this research were 180 Saanen does with a firstlactating record. The estimated genetic parameter was heritability score using a paternal half-sib correlation method. Result showed that the heritability of milk yield, kid birth weight, density, fat content, protein, lactose, water and NFDM was $0.32 \pm 0.23 ; 0.25 \pm 0.26 ; 0.15 \pm 0.17 ; 0.11 \pm 0.16 ; 0.12 \pm 0.16 ; 0.10 \pm$ $0.14 ; 0.10 \pm 0.16$ and $0.11 \pm 0.16$, respectively. A high $\mathrm{h} 2$ was obtained from heritability score of milk yield, and a moderate $h^{2}$ was from kid birth weight and milk quality. In conclusion, the $h^{2}$ score of milk yield of Saanen goats was relatively high, while the $h^{2}$ score of kid birth weight and milk quality were relatively moderate.
\end{abstract}

Keywords: heritability, milk yield, kid birth weight, milk quality, Saanen goat

Abstrak. Penelitian ini bertujuan menyelidiki nilai heritabilitas $\left(\mathrm{h}^{2}\right)$ produksi susu, bobot lahir kambing, dan kualitas susu yang mencakup kepadatan, kandungan lemak, protein, laktosa, air dan bahan kering non lemak kambing Saanen menurut catatan produksi kambing yang baru pertama kali menyusui di Balai Besar Pembibitan Ternak Unggul, Baturraden. Bahan penelitian ini adalah 180 kambing Saanen betina yang pertama kali menyusui. Parameter genetik yang diestimasi adalah nilai heritabilitas dengan metode paternal half-sib correlation. Hasil penelitian menunjukkan bahwa nilai heritabilitas produksi susu, bobot kambing, kepadatan, kandungan lemak, protein, laktosa, air dan bahan kering non lemak berturut-turut adalah $0.32 \pm 0.23 ; 0.25 \pm 0.26 ; 0.15 \pm 0.17 ; 0.11 \pm 0.16 ; 0.12 \pm 0.16 ; 0.10 \pm 0.14 ; 0.10 \pm 0.16$ and $0.11 \pm$ 0.16. $\mathrm{h} 2$ tinggi diperoleh dari produksi susu, dan $\mathrm{h} 2$ sedang pada bobot lahir kambing dan kualitas susu. Disimpulkan bahwa nilai $h^{2}$ produksi susu kambing Saanen relatif tinggi, sedangkan nilai $h^{2}$ bobot lahir kambing dan kualitas susu relatif sedang.

Kata kunci: heritabilitas, produksi susu, bobot lahir kambing, kualitas susu, kambing Saanen

\section{Introduction}

Saanen goat is a dairy goat from Saanen valley, western Switzerland. In Indonesia, Saanen goats have adapted the tropical climate and produced milk one to three $\mathrm{kg} / \mathrm{head} /$ day compared to five $\mathrm{kg} /$ day in subtropical region (Zuriati et al., 2011). According to Winarno and Fernandez (2007), Saanen goat is a renowned producer of quality milk with as low as $4.59 \%$ fat (Zurriyati et al., 2011); therefore, Saanen goat is the potential dairy goat breed.

Saanen goat exhibits a relatively optimum milk yield, which can be increased by improving the genetic quality. The result of genetic selection is quantitative and qualitative characteristics that are controlled by genetic and environmental factors. Heritability is a genetic parameter to measure the extent of heritable characteristics to the offspring. Heritability score is used to estimate the selection result.

Besides milk yield, some characteristics of Saanen goats that could be improved are kid birth weight and milk quality that includes density, fat content, protein, lactose, water and non-fat dry matter (NFDM). Safaa et al. (2015) reported that $h^{2}$ score of Saanen birth weight was $0.39 \pm 0.14$. According to Castaneda-Bustos et al. (2014), the $h^{2}$ score of milk yield and milk fat were similar $(0,37 \pm$ 
$0,02)$ and the $h^{2}$ of milk protein was $0,38 \pm$ 0,02 . Accordingly, it is crucial to conduct a study to estimat the genetic parameter (heritability) of milk yield, kid birth weight, and milk quality of Saanen goat.

The objective of this study was to investigate the heritability score $\left(\mathrm{h}^{2}\right)$ of milk yield, kid birth weight, and milk quality of Saanen goat. The added value of heritability $\left(h^{2}\right)$ estimates on milk yield, kid birth weight and milk quality of Saanen goat was to evaluate the extent of heritable characteristics to the offspring as the foundation of estimating selection result for breeding does.

\section{Materials and Methods}

The study was conducted from August $29^{\text {th }}$ to October $9^{\text {th }} 2019$ in BBPTU-HPT Baturraden, and the data were analyzed in the Laboratory of Livestock Preservation, Animal Science Faculty, Jenderal Soedirman University, Purwokerto. The observed variables were (1) milk yield (2) kid birth weight (3) milk quality (density, fat, protein, lactose, water content, and non-fat dry matter).

\section{Sampling method}

The study applied a survey method by tracking the record of 180 first-lactating Saanen does that were selected with a purposive sampling technique. The collected data were primary and secondary data, comprising a quantitative data in the form of production record of Saanen goat in BBPTUHPT Baturraden that included daily milk yield of the first lactation, kid birth weight and milk quality (density, fat content, protein, lactose, water content, and non-fat dry matter).

\section{Data analysis}

The secondary data were subject to analysis. Data correction was conducted to eliminate the unobserved variables. The correction to kid birth weight data used a local the guideline of post-calving correction factor (Hardjosubroto, 1994). The corrected data were subject to analysis of Completely Randomized Design One-way Classification in a mathematical model (Hardjosubroto, 1994):

$\mathrm{Yij}=\mu+\mathrm{Pi}+\mathrm{Eij}$

Note:

$\mathrm{Yij}_{\mathrm{ij}}=$ observation value of one characteristic from offspring number-j from male number-i

$\mu \quad=$ the average population

$\mathrm{Pi}=$ the influence of male number- $\mathrm{i}$

Eij = the influence in male number-i and doe number-j (uncontrolled environmental factor).

The data were analyzed based on heritability score $\left(\mathrm{h}^{2}\right)$ using an analysis of variance of Paternal Half sib Correlation. The formula for estimating $\mathrm{h}^{2}$ is as follows:

$\mathrm{h}^{2}=4 \mathrm{t}$

$t=\frac{\sigma_{s}^{2}}{\sigma_{w}^{2}+\sigma_{s}^{2}}$

Note:

$\mathrm{h}^{2}=$ heritability score

$\mathrm{t}=$ variance of half sib

$\sigma^{2}{ }_{w}=$ inter-individual variance in an offspring group

$\sigma^{2}{ }_{s}=$ variance among the average offspring groups in male

\section{Results and Discussions}

Milk yield, kid birth weight and milk quality

The average milk yield, kid birth weight and milk quality of Saanen goat in BBPTU-HPT Baturraden are presented in Table 2. The variance of milk yield and quality was estimated to have derived from season factor, while the variance of kid birth weight may due to different doe's age, birth method and sex. Birth weight is an important factor in livestock as it sets the parameter for further development. Kaswati et al. (2013) reported that birth weight could be 
Nurreni Irawati et al/Animal Production. 21(1):16-21, 2019

Accredited by Kemenristek Dikti No 32a/E/KPT/2017. ISSN 1411-2027

development. The number of kids per calving and sex contribute to birth weight.

Table 2 shows that the average milk yield of the first lactating Saanen goat in this study was lower than by Riswanti et al. (2012) $419.64 \pm 192.19$ I. Milk yield of Saanen goat in the tropical area is $1.0-3.0$ liter/day (Devendra and McLeroy, 1982). The average daily milk yield of Saanen goat in this study was relatively low due to environmental factors such as feed, breeding management, and seasons. Different calving seasons is correlated with the temperature of livestockenvironment and feed supply primarily forage; therefore, it is considered the contributing factor to different milk yield (Fuyuma, 2008). Maximum milk yield is obtained between the fourth and fifth year or during the third lactation and does not decline sharply for the next three years. Milk yield increases each day since the gestation period then gradually declines until the end of lactation.

The average kid birth weight of male goat was lower $(3.21 \pm 0.72 \mathrm{~kg})$ than that by Khandoker et al. (2018) (3.23 $\pm 062 \mathrm{~kg})$, but the female had a higher birth weight $(2.89 \pm$ $0.33 \mathrm{~kg}$ compared to $2.75 \pm 0.58 \mathrm{~kg}$ ). The different average birth weight was due to the variance in birth weight and doe's age when calving. Doe's age was used as the selection criteria because doe's production increase as it gets older (Hardjosubroto, 1994). According to Devendra and Burns (1994), birth weight of single Saanen goat was $3.4 \mathrm{~kg}$, and the twins were $2.85 \mathrm{~kg}$. The average kid birth weight for single calving in this study was higher than that of twins. Similarly, Khandoker et al. (2018) reported $3.07 \pm 0.60 \mathrm{~kg}$ and $2.7 \pm 0.28$ $\mathrm{kg}$ for a twin birth. Twins or triplets calving tend to have a lower birth weight (Gebrulul et al., 1994). Cattle with low birth weight have lower conserved energy which prevented them from enduring an extreme environmental condition (Curtis, 1969). The average milk density in this study was lower than that of the Thai Agricultural Standard (TAS) No. 6006, (2008), namely 1,0280. According to Legowo et al. (2009), milk density relies on fat content and milk solid matter because fat density is lower than water density or milk plasma. An increased density of goat milk may due to the escape gases like $\mathrm{CO}_{2}$ and $\mathrm{N}_{2}$ in the fresh milk (Rosartio et al., 2015). The average fat content in this study was below the standard by TAS No. 6006 (2008), namely $3.25-3.5 \%$, but within the standard quality. The contributing factors to fat content include forage and concentrate for

Table 2. Mean, standard deviation, and coefficient of variance of milk yield, kid birth weight and milk quality of Saanen goat

\begin{tabular}{lcc}
\hline Characteristics & Mean \pm standard deviation & Coefficient of Variance (\%) \\
\hline Milk yield & $230.20 \pm 40.42$ liter & 17.56 \\
Kid birth weight & $3.21 \pm 0.72 \mathrm{~kg}$ & \\
$\quad$ Male & $2.89 \pm 0.33 \mathrm{~kg}$ & 22.43 \\
Female & $3.02 \pm 0.21 \mathrm{~kg}$ & 11.51 \\
Twin & $3.04 \pm 0.65 \mathrm{~kg}$ & 6.21 \\
Single & & 21.38 \\
Milk quality & $1.03 \pm 0,001$ & \\
Density & $2.99 \pm 0.31 \%$ & 0.09 \\
Fat content & $3.12 \pm 0.20 \%$ & 10.47 \\
Protein & $3.07 \pm 0.18 \%$ & 6.38 \\
Lactose & $31.66 \pm 3.17 \%$ & 5.99 \\
Water content & $6.36 \pm 0.34 \%$ & 10.00 \\
Non-fat dry matter (NFDM) & & 5.28 \\
\hline
\end{tabular}


Nurreni Irawati et al/Animal Production. 21(1):16-21, 2019

Accredited by Kemenristek Dikti No 32a/E/KPT/2017. ISSN 1411-2027

feed. Forage affects fat formation because it contains high fiber. High acetate production would affect the fatty acid synthesis, which later increased the level of milk fat (Zain, 2013). According to TAS No. 6006 (2008), the standard protein level for fresh goat milk is 3.1 $-3.4 \%$, and the average protein in this study is relevant to the standard. The higher the protein in feed, the more protein secreted into milk, and the common source of protein feed is concentrate.

Lactose is the main carbohydrate in milk. Lactose in goat milk is lower by $0.2-0.5 \%$ than that of cow milk (Setiawan, 2013). The average lactose in this study was lower than 3.26 $4.71 \%$ by Mayer and Fiechter (2012). Milk yield is affected by milk water content, which in this study was relevant with SNI (1998) and TAS (2008) that required water content in milk under $89 \%$ and $87 \%$, respectively. Ensminger and Howard (2006) stated that water content in milk would generally increase in the first month after calving, and then decrease after peak lactation during the second and third month. In contrast, fat content increases towards the end of lactation. The actual milk quality value is in the non-fat dry matter (NFDM), which is the remaining dry matter after milk fat is eliminated (Tilman et al., 1986), and the average NFDM in this study was lower than the standard of TAS No 6006 (2008), namely $>8.25 \%$. The different non-fat dry matter is affected by lactose and protein: high lactose and milk protein would increase non-fat dry matter (Zurriyati et al., 2011).

The coefficient of variance reflects the degree of population size observed in the study - the higher the coefficient of variance, the more heterogenic the observed population. On the contrary, the lower the coefficient of variance, the more homogenous the observed population. The coefficient of variance in this study was in a low or (2008), the common method for estimating heritability score is paternal half sib moderate level. The characteristic diversity is low when the coefficient of variance is 0 $20 \%$, moderate at $20-50 \%$ and high at $>50 \%$. Budianto et al. (2009) reported that phenotypic diversity is essential for the selection process due to its genotypic variation. A tiny phenotypic variation would limit the selection process, or too few individual cattle to be selected, and vice versa.

\section{Heritability Milk yield, kid birth weight, and milk quality}

The estimate results of milk yield, kid birth weight, and milk quality are presented in Table 3. Heritability score of milk yield in this study was estimated using a Paternal Half sib Correlation method and generated a higher score than that of Fuyuma (2008), i.e., 0.32 which included in high category $(0.30-0.55)$ (Hardjosubroto, 1994). The high heritability score is expected to pass on milk yield characteristic to the offspring with an improved genetic development; therefore, the selection process would be useful (Bourdon, 1997). Previous studies reported that the average heritability of milk yield per lactation was 0.30 - 0.40 (Warwick et al., 1990; Martojo 1992), 0.25 (Pallawaruka, 1999) and $0.2-0.3$ (Johansson and Rendel, 1968). The different heritability estimate was due to a limited number of samples and differences in sampling techniques, methods, locations for scoring, and management.

Table 3 shows that heritability score of Saanan kid birth weight in this study was lower than $0.43 \pm 0.11$ (Kosum et al., 2004) and $0.39 \pm 0.14$ (Safaa et al., 2015). Heritability is a score between 0-1 with three categories: 0.0 - 0.1 is low; $0.1-0.3$ is moderate; and $>0.3$ is high (Adinata, 2013). The result of this study showed that heritability score of kid birth weight was in moderate range. According to Karnaen

correlation because it generates score similar to the actual one. 
Nurreni Irawati et al/Animal Production. 21(1):16-21, 2019

Accredited by Kemenristek Dikti No 32a/E/KPT/2017. ISSN 1411-2027

Table 3. The estimated heritability score of milk yield, kid birth weight and milk quality of Saanen goat

\begin{tabular}{lc}
\hline Characteristics & $\begin{array}{c}\text { Heritability } \pm \\
\text { standard deviation }\end{array}$ \\
\hline Milk yield & $0.32 \pm 0.23$ \\
Kid birth weight & $0.25 \pm 0.26$ \\
Milk quality & \\
1. Density & $0.15 \pm 0.17$ \\
2. Fat content & $0.11 \pm 0.16$ \\
3. Protein & $0.12 \pm 0.16$ \\
4. Lactose & $0.10 \pm 0.14$ \\
5. Water content & $0.10 \pm 0.16$ \\
6. Non-fat dry matter & $0.11 \pm 0.16$ \\
& \\
\hline
\end{tabular}

The estimated heritability of milk quality in this study was in moderate range, as stated by Dalton (1981) heritability score ranges from $0.00-0.10$ is low; $0.10-0.30$ is moderate; and $>0.30$ is high. A moderate to high heritability score indicates a more effective and efficient selection in improving genetic quality compared to that with low heritability score. Setyaningsih (2009) argued that a high heritability score is the potential criteria for selection because the high score is expected to pass on milk yield characteristics to the offspring and to exhibit an improved genetic; therefore, the selection would be effective. A high heritability score reflects a high diversity due to an additive genetic that affects a characteristic, while the rest are affected by the non-additive genetic (Kaswati et al., 2013). The estimated SE heritability of kid birth weight and milk quality in this study were higher than the heritability score. The high SE value was due to small data and high diversity within the male than among the males. The small data would result in high variance; therefore, a larger data was required to reduce the variance (Sari et al., 2016). The standard deviation is lower than the heritability score, reflecting a maximum heritability score (Kaswati et al., 2013). According to Warwick et al. (1990) and Hardjosubroto, (1994), heritability score is affected by different environment, analysis method, and sample size.

\section{Conclusions}

The $\mathrm{h}^{2}$ score of Saanen goat milk yield was relatively high $(0.32 \pm 0.23)$ while $h^{2}$ score of kid birth weight, density, fat content, protein, lactose, water and NFDM was relatively moderate around $0.25 \pm 0.26 ; 0.15 \pm 0.17$; $0.11 \pm 0.16 ; 0.12 \pm 0.16 ; 0.10 \pm 0.14 ; 0.10 \pm$ 0.16 and $0.11 \pm 0.16$, respectively.

\section{References}

Adinata, Y. 2013. Estimasi Nilai Pemuliaan Bobot Lahir Sapi Peranakan Ongole Pada Unit Pengelolaan Bibit Sumber di Loka Penelitian Sapi Potong. Seminar Nasional Teknologi Peternakan and Veteriner 2013. (Abstract in English)

Bourdon, R. M. 1997. Understanding Animal Breeding. Prentice Hall, Inc., Upper Suddle River, New Jersey.

Budianto, A., Ngawit and Sudika. 2009. Keragaman Genetik Beberapa Sifat dan Seleksi Klon Berulang Sederhana pada Tanaman Bawang Merah Kultivar Ampenan. Crop Agro.2(1): 1-7. (Abstract in English)

Castaneda-Bustos, V. J., H. H. Montaldo, G. TorresHernandez, S. Perez-Elizalde, M. ValenciaPosadas, O. Hernandez-Mendo and L. Shepard. 2014. Estimation of Genetic Parameters for Productive Life, Reproduction and MilkProduction Traits in US Dairy Goats. Journal Dairy Scince 97:2462-2473.

Curtis HJ (1969). Animal Growth and Nutrition. Lea and Fibger, Philadelphia, USA. pp.165-174.

Dalton, D. C. 1981. An Introduction to Practical Animal Breeding. Granada Publishing Limited, Technical Books Division. Fregmore, St. Albans, Herts.

Devendra, C. and G.B. McLeroy. 1982. Goat and Sheep Production in the Tropics. Intermediate Tropical Agriculture Series. London and New York.

Devendra and Burns. 1994. Produksi Kambing di Daerah Tropis. Penerbit ITB. Bandung.

Ensminger, M. E. and D. T. Howard. 2006. Dairy Cattle Science. 4th Ed. The Interstate Printers and Publisher, Inc. Danville.

Hardjosubroto, W. 1994. Aplikasi Pemuliabiakan Ternak di Lapangan. Grasindo Widiasarana Indonesia. Jakarta. 
Karnaen. 2008. Pendugaan Heritability Bobot Lahir and Bobot Sapih sebagai Dasar Seleksi Kambing Peranakan Etawah. Jurnal Ilmu Ternak.8(1): 5255. (Abstract in English)

Kaswati, Sumadi and N. Ngadiyono. 2013. Estimasi Heritability score Berat Lahir Sapih dan Umur Satu Tahun pada Sapi Bali di Balai Pembibitan Ternak Unggul Sapi Bali. Bulletin Peternakan.37(2): 74-78. (Abstract in English)

Khandoker, M. A. M. Y., N. Afini and A. Azwan. 2018. Productive and Reproductive Performance of Saanen Goat at Az-Zahra Farm of Sandakan in Malaysia. Bangladesh Journal Animal Science.47(1): 1-12.

Kosum, N., T. Taskin, Y. Akbas and M. Kaymakci. 2004. Heritability Estimates of Birth and Weaning in Saanen, Bornova and Saanen x Kilis Goats. Pakistan Journal of Biological Science. 7(1): 1963-1966.

Legowo, A. M., Kusrahayu and S. Mulyani. 2009. IImu and Teknologi Susu. Badan Penerbit Universitas Diponegoro. Semarang.

Martojo, H. 1992. Peningkatan Mutu Genetik Ternak. Departemen Pendidikan and Kebudayaan Dirjen - Dikti. PAU. Bioteknologi, Institut Pertanian Bogor, Bogor.

Mayer, H. K.and G. Fiechter. 2012. Physicochemical Characteristic of Goats Milk in Austria-seasonal Variations and Differences between Six Breeds. Diary Science and Technology.92(2): 167-177.

Riswanti, I., S. B. Komar and H. Indrijani. 2012. Pendugaan Kemampuan Milk yield pada Saanen goat di Taurus Diary Farm. Laporan Penelitian. Fakultas Peternakan Universitas Padjajaran. Bandung.

Rosartio, R., Y. Suranindyah, S, Bintara and Ismaya. 2015. Produksi and Komposisi Susu Kambing Peranakan Ettawa di Dataran Tinggi and Dataran Rendah Daerah Istimewa Yogyakarta. Buletin Peternakan.39(3): 180-188. (Abstract in English)

Safaa, A. A., I. A. Ishaq and M. K. A. Ahmed. 2015. Genetic and Environmental Factors Affecting Reproduction of Saanen Goats Raised Under Sudan Conditions. American Journal of Agricultural Science.2(3): 75-79.

Sari, E. M., M. A. Nashri and C. Hasnani. 2016. Estimasi Heritability score Sifat Kuantitatif Sapi Aceh. Agripet.16(1): 37-41. (Abstract in English)
Setiawan, J., R. R. A. Maheswari and B. P. Purwanto. 2013. Sifat Fisik and Kimia, Jumlah Sel Somatik and Kualitas Mikrobiologis Susu Kambing Peranakan Etawa. Acta Veterinaria Indonesiana.1(1): 32-43. (Abstract in English)

Setyaningsih, D. W. 2009. Efisiensi Seleksi Sapi Perah Fries Holland Berdasarkan Lingkar Dada, Bobot Badan and Umur. Media Soerjo.4(1): 115. (Abstract in English)

Standar Nasional Indonesia. 1998. Standar Mutu Susu Segar No. 01-3141-1998. Departemen Pertanian. Jakarta.

Thai Agricultural Standard. TAS 6006-2008. Raw Goat Milk. National Bureau of Agricultural Commodity and Food Standards, Ministry of Agriculture and Cooperatives. ICS 67.100.01. Published in the Royal Gaze tte.125 Section 139 D. Thailand.

Tilman, A. D., H. Hartadi, S. Reksohadiprojo, S. Prawirikusumo and S. Lebdosoekojo. 1986. IImu Makanan Ternak Dasar. Yogyakarta: Universitas Gadjah Mada.

Warwick, E. J., J. M. Astuti and Hardjosubroto. 1990. Pemuliaan Ternak. Gadjah Mada University Press. Yogyakarta.

Warwick, E.J., W. Hardjosubroto and J.M. Astuti. 1995. Pemuliaan Ternak. Gadjah Mada University Press. Yogyakarta.

Winarno, F. G. and E. I. Fernandez. 2007. Susu and Produk Fermentasinya. MBRIO PRESS. Jakarta.

Zain, W. N. H. 2013. Kualitas Susu Kambing Segar di Peternakan Umban Sari dan Alam Raya Pekanbaru. Jurnal Peternakan.10(1): 24-30. (Abstract in English)

Zuriati, Y., R. R. A. Maheswari and H. Susanty. 2011. Karakteristik Kualitas Susu Segar and Yoghurt dari Tiga Bangsa Kambing Perah dalam Mendukung Program Ketahanan and Diversifikasi Pangan. Seminar Nasional Teknologi Peternakan and Veteriner. Hal. 613619. (Abstract in English)

Zurriyati, Y., R. R. Noor and R. R. A. Maheswari. 2011. Analisis Molekuler Genotipe Kappa Kasein (к-kasein) and Komposisi Susu Kambing Peranakan Etawah, Saanen and Persilangannya. Jurnal Ilmu Ternak and Veteriner.16(1): 61-70. (Abstract in English) 